\title{
ADVERTISING EFFECTIVENESS IN PURCHASING DECISION ON INSTAGRAM
}

\author{
Luh Putu Ayu Wulandari', Gede Sri Darma ${ }^{2}$ \\ Pendidikan Nasional University, Indonesia \\ 1ohtu22@gmail.com, sridarma@undiknas.ac.id
}

\begin{abstract}
The aim of this research is to observe the impact of advertising creativity, advertising appeal and endorser credibility to the advertising effectiveness and purchase decision on Instagram. This research was conducted in Ilsproject Store. It is an online and offline store in Denpasar which sells fashion product. The design of this research is a quantitative research which shows a causality relationship between variables. The technique of collecting data was done using questionnaire to 168 consumers. The technique of analyzing data was done using structural equation modeling (SEM) with the AMOS program version 22. The result of this research shows that the advertising creativity has a positive and significant impact of 0,783 to the advertising effectiveness and 0,203 to the purchase decision. The advertising appeal has a positive and significant impact of 0,783 to the advertising effectiveness and 0,648 to the purchase decision. The endorser credibility has a positive and significant impact of 0,803 to the advertising effectiveness and 0,656 to the purchase decision. The advertising effectiveness has a positive and significant impact to the purchase decision with the number 0,831 .
\end{abstract}

Keywords: advertising creativity, advertising appeal, endorser credibility, advertising effectiveness and purchasing decision

\section{INTRODUCTION}

Instagram is a social media application which currently ranks the $4^{\text {th }}$ position as much as $38 \%$. It has a special feature for business account. It also has a new feature which currently very popular, named Instastory. Instastory is a feature where we can post any activity that we do to Instagram. Thus, the Instastory users promote indirectly what they have recorded by using this feature. As time goes by, many people have been realized that Instagram can be used as a tool for selling their product.

Instagram is one of the social media with many online shops inside which currently appears as a beneficial business. Instagram has become a distinctive phenomenon among social media users, especially teenagers (Kurniawati \& Arifin, 2015). Although there are many social media that frequently used by people, Instagram itself is no less popular. Many people take advantage of Instagram as a tool for doing their business by uploading the photo of the product which they choose to be promoted with some variation of filters that can attract the buyers. 
Advertising a product through Instagram Marketing is usually supported by the influence from influencer. Influencer is someone who usually acts as an influence giver since their view, advice or opinion would encourage the purchasing decision. Many advertising can be done in Instagram by the help of endorsement. With the presence of influencer marketing strategy model, it is expected to increase the consumer decision in making a purchase. There are a lot of factors which company should consider in designing an advertisement in order to influence the consumer in their purchasing decision. The main factor which should be considered by the company is the appeal of the advertisement itself. The advertising appeal can be done with the innovation of the advertising creativity in order to be able to attract the consumer interest. Aside from advertising creativity, the credibility of endorser can also influence the advertising effectiveness which will impact the increasing of consumer decision to make a purchase of the advertised product. This will eventually help improve economy and attract investment to bring more benefit (Lestari, 2015).

There are many studies that have been conducted about the influencer marketing strategy with the purpose to increase the sale. The research which conducted by (Andayani et al., 2016) found that the more creative the advertising is, the higher the appeal of the advertising will be. Besides, another result of the research also found that the higher the endorser credibility is, the higher the advertising appeal will be. The advertising appeal, advertising creativity and endorser credibility give an impact to the advertising effectiveness.

The other research which conducted by (Faizan, 2014) also found that the advertising creativity and endorser give a positive and significant impact to the process of purchase decision. Meanwhile, the result of the partial test found that advertising creativity has a positive and significant impact to the process of purchase decision. In the other hand, endorser also gives a positive and significant impact to the process of purchase decision. The better the advertising creativity is, the stronger the purchase decision process will be. Also, the more influential the endorsers, the stronger the purchase decision process will be. The process of purchase decision will be stronger if the advertising and endorser creativity are also improved.

The aim of this research is to observe the impact of advertising creativity, advertising appeal and endorser credibility to the advertising effectiveness and purchase decision on Instagram.

\section{METHODOLOGY}

This research was conducted in Ilsproject Store. It is an online and offline store in Denpasar which sells fashion product. The design of this research is a quantitative research which shows a causality relationship between variables; Advertising Creativity, Advertising Appeal, Endorser Credibility, Advertising Effectiveness and Purchase Decision. The technique of collecting data was done using questionnaire to 168 consumers. The technique of analyzing data was done using structural equation modeling (SEM) with the AMOS program version 22. 


\section{RESULT AND DISCUSSION}

Since the empiric data in this research are taken from questionnaire, therefore before starting the analysis using SEM, the research instrument test would be done first. The research instrument test was done by using validity test and reliability test. After the data were valid and reliable, the next step was normality test, CFA and SEM using AMOS program version 22. The result of the analysis shows in the picture below.

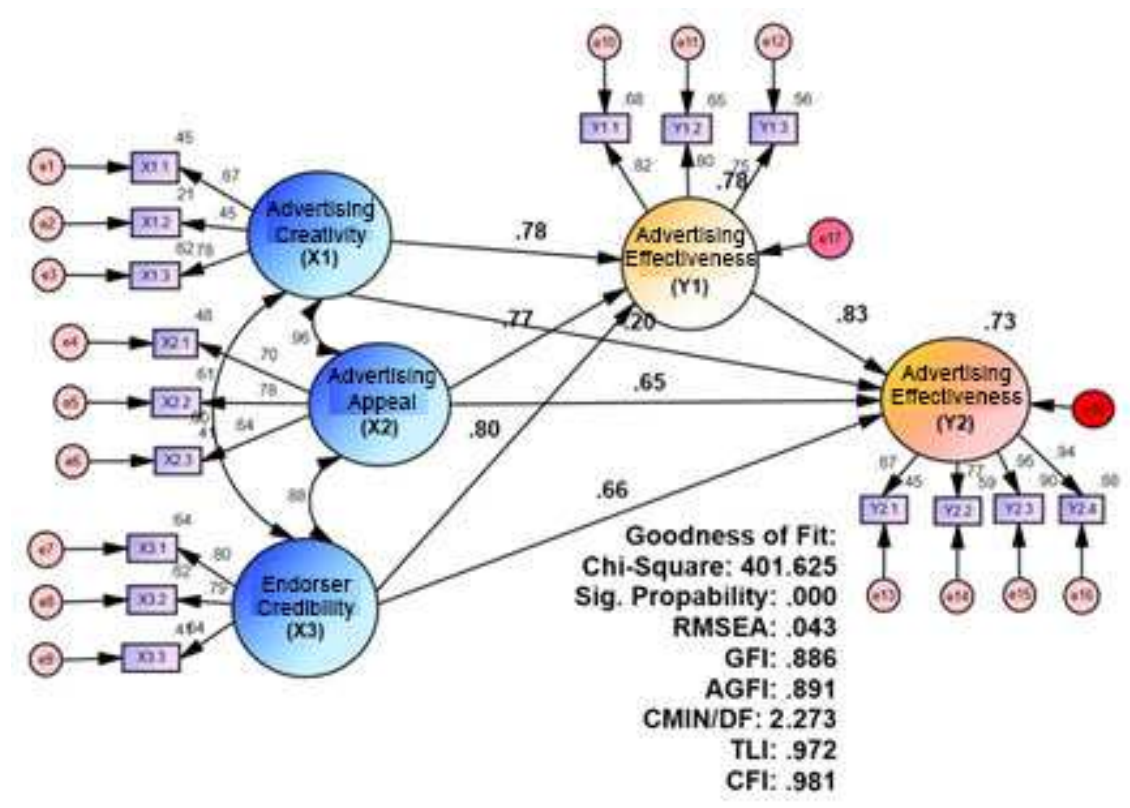

The Full Mode Analysis Result of Causality Relationship Impact between Advertising Creativity, Advertising Appeal, Endorser Credibility, Advertising Effectiveness and Purchase Decision.

The testing model was conducted by using the regression weight for the variable of advertising creativity, advertising appeal, endorser credibility, advertising effectiveness and purchase decision through output table as written below.

Table 1. Regression Weight Structural Unstandardized and Standardized Measurement Model

$\begin{array}{rrrrrr}\text { Unstandarized } & \text { Standarized } & \text { S.E. } & \text { C.R. } & \text { P } & \text { Ket } \\ \text { Estimate } & \text { Estimate } & & & & \end{array}$

\begin{tabular}{lllrrrrrl}
\hline Y1 & $<---$ & X3 & .709 & .803 & .449 & 3.577 & $* * *$ & Sig \\
Y1 & $<---$ & X2 & .786 & .772 & 1.762 & 2.446 & .003 & Sig \\
Y1 & $<---$ & X1 & 1.043 & .783 & 1.818 & 2.574 & .001 & Sig \\
Y2 & $<---$ & Y1 & 1.189 & .831 & .407 & 3.922 & $* * *$ & Sig \\
Y2 & $<---$ & X3 & .668 & .656 & .495 & 2.348 & .028 & Sig \\
Y2 & $<---$ & X2 & .760 & .648 & 1.796 & 2.423 & .005 & Sig
\end{tabular}




$\begin{array}{lllllllll}\text { Y2 } & <-- & \mathrm{X} 1 & .313 & .203 & 1.864 & 2.168 & .047 & \text { Sig }\end{array}$

Source: research data, 2020

According to the analysis result with the path analysis as written above, it can be explained that all variables have a C.R (critical ratio) value above 2,000 and sig value is lower than 0,05 . This means that all exogenous variables have a significant direct impact on the exogenous variables. Meanwhile, the testing result of indirect impact of the advertising creativity, advertising appeal and endorser credibility to the purchase decision using advertising effectiveness is written in the table below.

Table 2. Indirect Impact

\begin{tabular}{lccccc}
\hline & $\begin{array}{c}\text { Advertising } \\
\text { Creativity }\end{array}$ & $\begin{array}{c}\text { Endorser } \\
\text { Credibilit } \\
\mathrm{y}\end{array}$ & $\begin{array}{c}\text { Advertisin } \\
\text { g Appeal }\end{array}$ & $\begin{array}{c}\text { Advertising } \\
\text { Effectivenes } \\
\mathrm{s}\end{array}$ & $\begin{array}{c}\text { Purchas } \\
\mathrm{e} \\
\text { Decisio } \\
\mathrm{n}\end{array}$ \\
\hline $\begin{array}{l}\text { Advertising } \\
\text { Effectivenes } \\
\mathrm{S}\end{array}$ & .000 & .000 & .000 & .000 & .000 \\
$\begin{array}{l}\text { Purchase } \\
\text { Decision }\end{array}$ & .651 & .667 & .642 & .000 & .000 \\
\hline
\end{tabular}

Source: research data, 2020

The second table above shows that the indirect impact of advertising creativity to the purchase decision through advertising effectiveness is as much as 0,651 . The indirect impact of endorser credibility to the purchase decision through advertising effectiveness is as much as 0,667 and the indirect impact of advertising appeal to the purchase decision through advertising effectiveness is as much as 0,642 .

\section{The Impact of Advertising Creativity to the Advertising Effectiveness}

According to the analysis result, it can be identified that the direct impact of advertising creativity to the advertising effectiveness has a C.R value as much as 2,547 with the probability $0,001<0,05$. This means, advertising creativity has a positive and significant impact to the advertising effectiveness. Therefore it can be said that the higher the advertising creativity is, the higher the advertising effectiveness will be which also agreed by the research conducted by (Legasari, Indarti \& Restuti, 2013). They found that advertising creativity gives a positive and significant impact to the advertising effectiveness. The creative advertising design will make the design doing its persuasive function to the consumer effectively. The same idea also proposed by (Eva, 2012). In her research which entitled Case Study on the Advertising of Olay Natural White in Semarang City, it is found that the testing to the variable of advertising creativity and advertising effectiveness shows the fourth hypothesis. The hypothesis tells that "the more creative the advertising is, the higher the advertising effectiveness will be". It can be accepted and proved 
statistically. Moreover, (Handika dkk, 2018) found that the use of social media marketing especially Instagram, may press the cost in marketing.

\section{The Impact of Advertising Appeal to the Advertising Effectiveness}

According to the analysis result, it can be identified that the direct impact of advertising appeal to the advertising effectiveness has a C.R value as much as 2,466 with the probability $0,003<0,05$. This means, advertising appeal has a positive and significant impact to the advertising effectiveness. Therefore it can be said that the higher the advertising appeal is, the higher the advertising effectiveness will be, which also agreed by (Sufa \& Munas Bambang, 2012) in their research. They state that the advertising that delivers by words and illustration that easy to understand will attract the consumers easier since the advertising appeal or power of impression from the advertisement means to attract the attention from their viewers. The advertising appeal is really important since it will grow the effectiveness of communication with the audience. Basically, every consumer wants to buy a high quality product. However if the quality between some products are equal, this may lead the consumers to choose one product based on its advertising. Therefore, the advertising appeal may influence the consumer's perception with the aim to make the advertising effective. (Handika $\mathrm{dkk}, 2018$ ) found that the use of social media marketing especially Instagram, may press the cost in marketing.

Furthermore, the research by (Sufa \& Munas Bambang, 2012) on the Mie Sedap advertising survey shows that the variable of advertising appeal has a positive and significant impact to the advertising effectiveness. This means, the advertising appeal is one of the factors which can increase the advertising effectiveness. The impact of appeal to the advertising effectiveness is as much as 0,281 . The same idea is also proposed by (Hastuti, 2013) in her research about the public service advertisement of $3 \mathrm{Kg}$ LPG gas which showed on TV. She claims that the advertisement is effective enough if we look to the quality of the message, advertising appeal and the frequency of advertising serving. The most influential variable is advertising appeal. The attractive advertisement will be able to influence the behaviour of the audience to act in accordance with the purpose which delivered in the advertisement. Therefore, the proper appeal will increase the advertising effectiveness.

\section{The Impact of Endorser Credibility to the Advertising Effectiveness}

According to the analysis result, it can be identified that the direct impact of endorser credibility to the advertising effectiveness has a C.R value as much as 3,577 with the probability $* * *<0,05$. This means, the endorser credibility has a positive and significant impact to the advertising effectiveness. Therefore it can be said that the better the endorser credibility is, the higher the advertising effectiveness will be, which also agreed by (Imanita, 2017) in the result of her research. She states that endorser credibility has an impact to the interpretation process of a message. If the endorsers can be trusted by the consumer, it is quite possible that the message which they deliver in their advertising will be trusted too. The credible endorser may increase the acceptance level of the message. On the contrary, the non-credible endorser may reduce the acceptance level of the message. 
The other research was proposed by (Eva, 2012) about Case Study on the Advertising of Olay Natural White in Semarang City. She also used the variable of endorser credibility and advertising effectiveness. Moreover, after it is tested, the fifth hypothesis of the result states that "the higher the endorser credibility is, the effective the advertising will be" which can be accepted and proved statically. Futhermore, (Handika dkk, 2018) found that the use of social media marketing especially Instagram, may press the cost in marketing.

\section{The Impact of Advertising Creativity to the Purchase Decision}

According to the analysis result, it can be identified that the direct impact of advertising creativity to the purchase decision has a C.R value as much as 2,168 with the probability $0,047<0,05$. This means, the advertising creativity has a positive and significant impact to the purchase decision. Therefore it can be said that the more creative the advertising is, the stronger the purchase decision will be, which also agreed by (Kotler and Keller, 2016) in the result of their research. They state that the good advertising mainly focused on the selling core consists of attractive things from the brand or stating something exclusive and different that cannot be found in other brand. Therefore it can convince the consumer that they need this brand. The effort to get and maintain the attention is by planning the message very well to make it imaginative, entertaining and beneficial for the consumers (Rizal \& Furinto, 2015). Hence, the advertisement will become attractive and may influence the purchase decision. This is supported by the analysis result which done by (Hardetama, 2017) states that advertising creativity has a positive impact to the purchase decision.

\section{The Impact of Advertising Appeal to the Purchase Decision}

According to the analysis result, it can be identified that the direct impact of advertising appeal to the purchase decision has a C.R value as much as 2,423 with the probability $0,005<0,05$. This means, the advertising appeal has a positive and significant impact to the purchase decision. Therefore it can be said that the higher the advertising appeal is, the stronger the purchase decision will be, which also agreed by (Hamidah, 2017) in her research. Hamidah found that the advertising appeal has a significant impact to the purchase decision. The same research also conducted by (Khusnaeni, Yulianto \& Sunarti, 2017) which found that advertising appeal has a positive impact to the purchase decision. The better the advertising appeal is, the stronger the purchase decision for the consumer in doing a purchase.

\section{The Impact of Endorser Credibility to the Purchase Decision}

According to the analysis result, it can be identified that the direct impact of endorser credibility to the purchase decision has a C.R value as much as 2,348 with the probability $0,028<0,05$. This means, the endorser credibility has a positive and significant impact to the purchase decision. Therefore it can be said that the better the endorser credibility is, the stronger the purchase decision will be, which also agreed by (Faizan, 2014). His partial testing result shows that endorser has a positive and significant impact to the purchase decision. The better the endorser used, it will increase the purchase decision process and the purchase decision process will be increase if the advertising creativity and endorser are improved. 
(Sebayang \& Siahaan, 2018) in their analysis result found that celebrity endorser has an impact to the purchase decision.

\section{The Impact of Advertising Effectiveness to the Purchase Decision}

According to the analysis result, it can be identified that the direct impact of advertising effectiveness to the purchase decision has a C.R value as much as 3,922 with the probability $* * *<0,05$. This means, the advertising effectiveness has a positive and significant impact to the purchase decision. Therefore it can be said that the more effective the advertising is, the stronger the purchase decision will be, which also agreed by (Kairupan, 2013). Kairupan's analysis shows that advertising effectiveness has a significant impact to the purchase decision. The effectiveness of the advertising can be looked from two impacts, which are: the communication impact from an advertisement which consists of the impact of awareness, knowledge and preference and the second is the impact to the sale which is harder to measure since the sale is influenced by many factors, not only by advertising.

\section{CONCLUSION}

The advertising creativity has a positive and significant impact to the advertising effectiveness. This means, the higher the advertising creativity is, the higher the advertising effectiveness will be. The advertising appeal has a positive and significant impact to the advertising effectiveness. This means, the higher the advertising appeal is, the higher the advertising effectiveness will be. The endorser credibility has a positive and significant impact to the advertising effectiveness. This means, the higher the endorser credibility is, the higher the advertising effectiveness will be. The advertising creativity has a positive and significant impact to the purchase decision. This means, the higher the advertising creativity is, the higher the purchase decision will be. The advertising appeal has a positive and significant impact to the purchase decision. This means, the higher the advertising appeal is, the higher the purchase decision will be. The endorser credibility has a positive and significant impact to the purchase decision. This means, the higher the endorser credibility is, the higher the purchase decision will be. The advertising effectiveness has a positive and significant impact to the purchase decision. This means, the higher the advertising effectiveness is, the higher the purchase decision will be.

\section{REFERENCES}

Hastuti, S. (2013). Efektivitas Iklan Layanan Masyarakat Di Televisi. Jurnal Ilmu Komunikasi, 2(2), 1-82. $\quad$ Retrieved from https://ejournal.unri.ac.id/index.php/JKMS/article/viewFile/2554/2509

Hermawan, A. (2012). Komunikasi Pemasaran. Jakarta: Erlangga.

Handika Made Resi, Maradona Agus Fredy dan Darma Gede Sri. (2018). Strategi Pemasaran Bisnis Kuliner Menggunakan Influencer Melalui media Sosial Instagram. Jurnal Manajemen dan Bisnis. Vol. 15. No. 2. Hlm. 192-203 
Imanita, M. A. (2014). "Pengaruh Kredibilitas Perusahaan dan Kredibilitas Endorser pada Sikap Konsumen (terhadap Iklan dan Merek) dan Intensi Membeli". Jurnal Ilmiah Mahasiswa FEB, 1-12.

Kairupan, M. (2013). Sikap, Keyakinan Dan Efektivitas Iklan Pengaruhnya Terhadap Keputusan Penggunaan Produk Kartu As Konsumen Di Manado Town Square. Jurnal Riset Ekonomi, Manajemen, Bisnis Dan Akuntansi, 1(3), 1100-1110.

Kertamukti. (2015). Strategi Kreatif dalam Periklanan. Jakarta: PT Raja Grafindo Persada.

Khusnaeni, N., Yulianto, E., \& Sunarti, S. (2017). Pengaruh Iklan Terhadap Sikap Konsumen Serta Dampaknya Pada Keputusan Pembelian (Survei pada Mahasiswa S1 Universitas Brawijaya Malang Pengguna Kartu Seluler Telkomsel 4G LTE yang Pernah Melihat Iklan Telkomsel 4G LTE Versi âNixia Gamerâ). Jurnal Administrasi Bisnis S1 Universitas Brawijaya, 47(2), 49-56.

Kotler, Philip dan Keller, K. L. (2016). Marketing Management. Pearson Education Inc.

Kotler Phillip, K. L. K. (2012). Marketing Management 14th edition. Jakarta: PT. Indeks Kelompok Gramedia.

Kurniawati, D., \& Arifin, N. (2015). Strategi Pemasaran Melalui Media Sosial dan Minat Beli Mahasiswa. Jurnal Manajemen, 1(2), 194-195.

Legasari, V. E., Indarti, S., \& Restuti, S. (2013). Pengaruh Daya Tarik Iklan, Kreativitas Iklan Dan Kredibilitas Endorser Terhadap Efektivitas Iklan Dan Sikap Konsumen Pada Sabun Pemutih Wajah Merek Oil Of Olay Di Kota Pekanbaru. Jurnal Teknologi, 1(1), 69-73. https://doi.org/10.11113/jt.v56.60

Lestari, Denok. 2015. Developing Communicative Competence of the Students at the Bali Hotel School by Implementing Instructional Role Play. Journal of Business on Hospitality and Tourism. 1(1). http://jbhost.org/jbhost/index.php/jbhost/article/view/31

Mufarrih, Z. (2015). Periklanan Sebuah Pendekatan Praktis. Yogyakarta: Litera.

Rizal dan A. Furinto. (2015). Marketing Reloaded: Kompilasi Konsep dan Praktik Pemasaran. Jakarta: Salemba Empat

Sebayang dan Siahaan. 2018. Pengaruh Celebrity Endorser Terhadap Keputusan Pembelian Sepeda Motor Merek Yamaha Mio Pada Mio Automatik Club (MAC), Medan Jurnal Manajemen. Vol. 12, No. 2, Maret 2018, hal. 101116

Sufa, fella, \& Munas Bambang. (2012). Analisis Pengaruh Daya Tarik Iklan. Diponegoro Journal of Management, 1(1), 226-233. Retrieved from http://ejournal-s1.undip.ac.id/index.php/djom 
Sulistiono, Angga. 2012. “Analisis Pengaruh Iklan Televisi Terhadap Keputusan Pembelian Motor Yamaha Jupiter MX". Jurnal Ilmiah Kesatuan Nomor 1 Volume 14, April 2012.

Sumarwan, \& Ujang, D. (2011). Riset Pemasaran dan Konsumen : Panduan Riset dan Kajian: Kepuasan, Perilaku Pembelian, Gaya Hidup, Loyalitas dan Persepsi Resiko. Bogor: PT Penerbit IPB Press.

Tjiptono, F. (2015). Strategi Pemasaran. Yogyakarta: Penerbit Andi.

Walid. (2018). Penggunaan Instagram Sebagai Social Media Marketing Dalam Membangun Brand Awareness Platbm1912 Di Kota Pekanbaru. Jom Fisip, 5(1), 1-10.

Wibowo, D. H., Arifin, Z., \& Sunarti, . (2015). Analisis Strategi Pemasaran Untuk Meningkatkan Daya Saing UMKM (Studi pada Batik Diajeng Solo). Jurnal Administrasi Bisnis, 29(1), 59-66. Retrieved from http://administrasibisnis.studentjournal.ub.ac.id/index.php/jab/article/view/ 1172 